\title{
CASE STUDIES OF ANIMAL FEEDLOTS ON KARST IN OLMSTED COUNTY, MINNESOTA
}

\author{
Martin Larsen \\ Olmsted County Soil and Water Conservation District, 1485 Industrial Drive NW Rm 102, Rochester, MN 55901, \\ USA,Martin.Larsen@mn.nacdnet.net
}

\begin{abstract}
A unique area of Olmsted County is located a few miles southeast of Rochester by the small community of Predmore (Figure 1). Surface geology within the Orion Sinkhole Plain is dominated by a large array of sinkholes and limited soil cover over carbonate bedrock of the Ordovician Stewartville and Prosser Formations. Dye trace studies completed by Eagle and Alexander (2007) have demonstrated that a large portion of the plain's groundwater discharges into springs that feed two local trout streams. Land-use in the area is mixed. For generations, local farmers have relied on livestock for stable income and profit. To put the 8,000 acre region into perspective, there are approximately 3,600 animal units located at 12 facilities which produce an estimated 74 million pounds of manure per year (United States Department of Agriculture / Natural Resources Conservation Service, 1995) and 10 million gallons of manure contaminated runoff. (Larsen et al., 2014) 349 known karst features exist of which 316 are sinkholes (Alexander et al., 1988).
\end{abstract}

Following snowmelt and rain in March of 2013; an incident occurred where an area well was potentially impacted. Investigation revealed manure contaminated runoff was entering groundwater in a newly discovered sinkhole (Larsen, 2013). Local citizen concern grew for groundwater quality.

Developing relationships with landowners and livestock producers became necessary for protection of water resources and has facilitated research, education and action. A newly formed sinkhole that seasonally receives feedlot runoff was studied with ground penetrating radar for repair. Two producers in the region are implementing manure management techniques that are more stringent then regulation. The Wiskow dye trace was completed in spring of 2014. The study identified discharge springs that discharge into the Mill Creek trout stream from two vulnerable sinkholes (Johnson et al., 2014). Four springs and four previously unknown sinkholes were identified and mapped. A manure contaminated runoff storage area was constructed in the fall of 2014 by a livestock producer located at a headwater spring of Mill Creek. A filter strip and large manure contaminated runoff system is being designed for construction in 2015 .

Building great relationships with producers has been successful in Olmsted County. Livestock producers are making investments and taking action. Producers are an essential component of the mid-western economy and assistance with information, funding and resources will help protect the environment and keep farms profitable for future generations.

\section{Introduction}

A large array of sinkholes known as the Orion sinkhole plain is found south of Interstate 90 and north of the

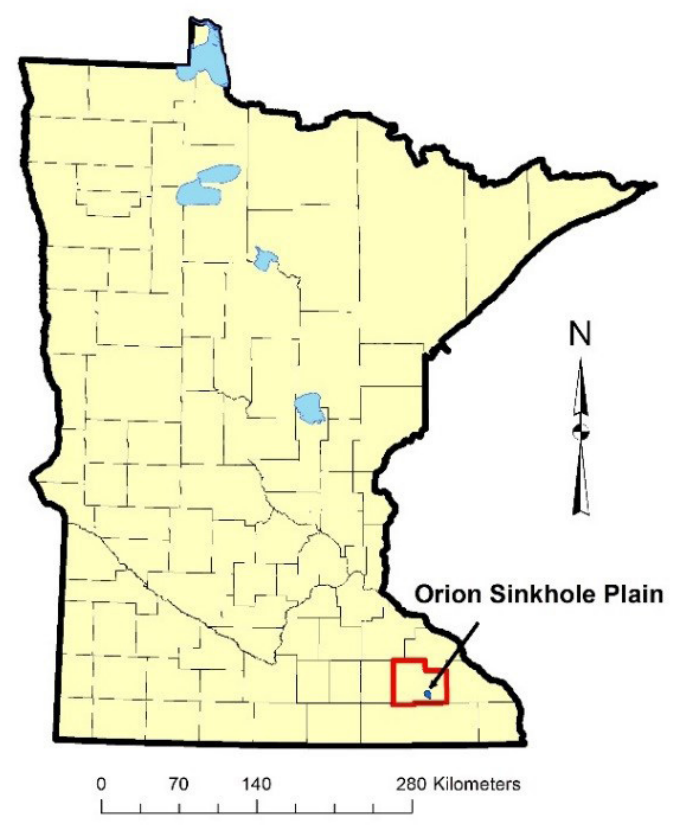

Figure 1. A state location map of the Orion Sinkhole Plain (Larsen, 2015).

14TH SINKHOLE CONFERENCE NCKRI SYMPOSIUM 5 
North Branch of the Root River; bordered to the west by Kinney Creek and on the east by Mill Creek (Johnson et al., 2014).

Surface geology of the Orion Sinkhole Plain is dominated by a large number of sinkholes and limited soil cover over carbonate bedrock of the Ordovician Stewartville and Prosser Formations (Figures 2 and 3). Dye trace studies completed by Eagle and Alexander (2007) and Green (2004) have demonstrated that a significant portion of the groundwater from the sinkhole plain discharges into springs that feed two local trout streams (Figure 5).

Land-use in the area is mixed. For generations, local farmers have relied on livestock for stable income and profit. The highly variable soil types are not well suited for farmers to depend exclusively on a cash grain cropping system. Within the 3,200 hectare $(8,000$ acre) region, there are approximately 3,600 animal units. Twelve facilities produce an estimated 34 million kilograms (74 million pounds) of manure per year (United States Department of Agriculture / Natural
Resources Conservation Service, 1995) and according to site evaluations, 39 million liters (10 million gallons) of manure contaminated runoff (Larsen, et al., 2014). 349 known karst features exist of which 316 are sinkholes (Alexander, et al., 1988).

Although karst geology is widespread across Olmsted County, unique challenges exist for the protection of water resources by livestock producers in this area. There are engineering complications for the design of manure storage structures that may hold millions of gallons of manure and manure-laden runoff. Proper investigation and siting must take place so that the risk of soil collapse or seepage from underneath the structure is minimized. Operational challenges exist for livestock producers who are applying manure in the study area not just in proximity to sinkholes. The entire area is underlain by a karst system with widespread dendritic, underground drainage that discharges to springs and streams. Proper manure management techniques must be developed and implemented to minimize the risk of manure contaminated runoff entering the groundwater system.

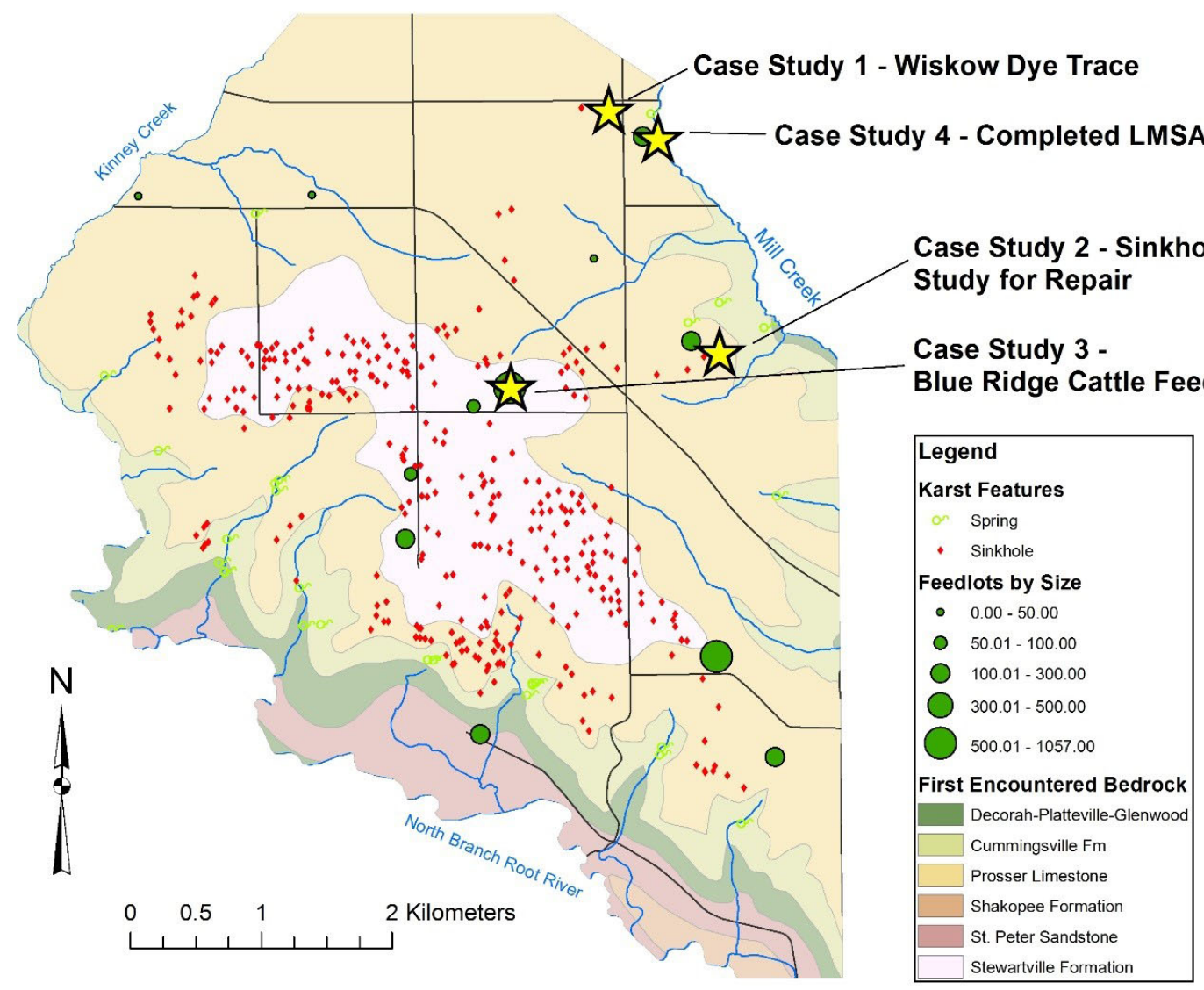

Figure 2. Map of the Orion Sinkhole Plain with Case Studies and Feedlots Identified (Larsen, 2015). 


\section{Stratigraphy of the Orion Sinkhole Plain}

\begin{tabular}{|c|c|c|c|c|}
\hline GP & FORMATION & GRAPHIC & DESCRIPTION & \\
\hline \multirow{4}{*}{ 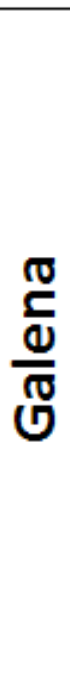 } & Stewartville & 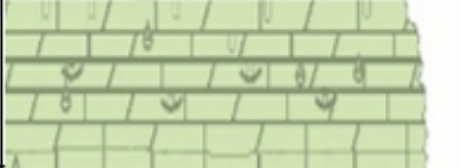 & $\begin{array}{l}\text { Fine Grained dolomite and dolomitic } \\
\text { limestone; weathered surfaces } \\
\text { appear pitted. }\end{array}$ & \multirow{4}{*}{ 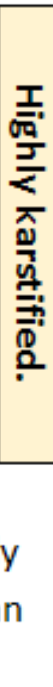 } \\
\hline & Prosser & $\longrightarrow$ & $\begin{array}{l}\text { Very Fined Grained, thin bedded } \\
\text { limestone that becomes dolomitic } \\
\text { near the top. }\end{array}$ & \\
\hline & Cummingsville & 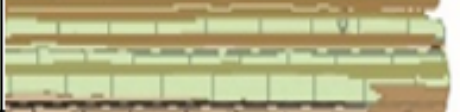 & $\begin{array}{l}\text { Very fine grained limstone and } \\
\text { interbedded calcareous shale. }\end{array}$ & \\
\hline & Decorah & 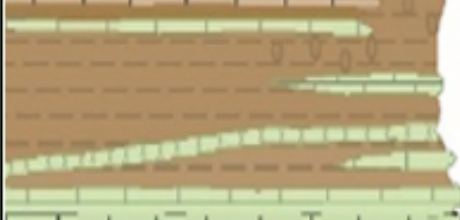 & $\begin{array}{l}\text { Green, calcareous shale with thin } \\
\text { interbeds of limestone and is commonly } \\
\text { very fossiliferous. Widely considered an } \\
\text { aquitard. }\end{array}$ & \\
\hline
\end{tabular}

Figure 3. Illustration of the stratigraphy in the Orion Sinkhole Plain (Alexander, et al., 1988).

The objectives of this study are to 1) show case studies and the problems encountered in the study area; and 2) to illustrate beneficial relationships between livestock producers, engineers, scientists and regulators that have had positive results and are essential. There is not a complete understanding of how current rules and engineering practices are performing in such dynamic karst environments. In order to enhance these standards and practices, parties must interact in a collaborative manner so that information, knowledge and feedback is shared.

\section{Case Study 1 - Concern for Groundwater and Dye Tracing to Determine Groundwater Flow}

Concern for groundwater contamination resulting from livestock production overlying karst systems has occurred many times in Olmsted County. Citizen trepidations commonly arise when new animal operation proposals are being considered. For example, in the late 1970s, two large swine facilities were proposed in the county. A contentious discussion between farmers, regulators, and other property owners focused on karst systems and groundwater quality. At one of the proposed sites, an Eyota area farmer constructed an un-permitted concrete block manure storage pit (which was excavated into the Galena Limestone). Following construction of the storage pit, a nearby private well in the Galena Limestone allegedly experienced "dark-colored" water and the renters' wife was hospitalized after ingesting that water in the fall of 1978 (Landherr, 1979, written communication).

More recently, an incident occurred on March 11, 2013, where a private well on the northern edge of the Orion sinkhole plain was potentially impacted with manurecontaminated runoff.

A series of climatic events created a "perfect storm" for runoff. Rainfall occurred early in the winter of 2012 2013 when there was limited snow cover in the region. As the winter progressed, little additional snow fell and

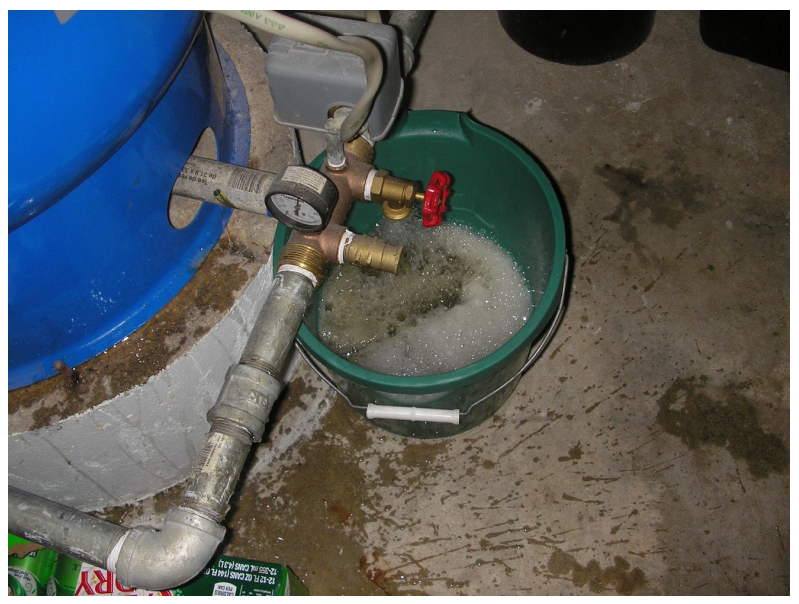

Figure 4. A pail of foaming water collected from the contaminated well. Foam can commonly occur in water contaminated with human or animal waste (Schmidt, 2013). 
temperatures dropped dramatically. The rain and snowmelt that occurred on March 8-10 was not able to infiltrate the ground that was sealed by ice and thick frost. Flowing water carried large amounts of manure contaminated runoff from farmland throughout southeast Minnesota.

During the week prior to March 11, 2013, a farmer applied cattle bedding pack on a field southern Eyota Township in compliance with all applicable federal, state and local laws. The field does not contain any obvious sinkholes. For the most part, soil is thin, the field has less than 5 feet of soil cover overlying the Prosser Limestone that is visible in outcrops within the field. Soil texture is mixed with sands and sandy loam inclusions.

According to a neighboring landowner, their well water became discolored and odorous following the manure applications and subsequent runoff event (Figure 4). The well, which is 43 meters deep, was constructed in the early 1950s has 6 meters of steel casing. It was drilled in the highly fractured and porous Ordovician Prosser Formation. It does not penetrate the lower Decorah Shale, which serves as a regional aquitard (Figure 3).

County and Minnesota Pollution Control Agency response lasted many weeks. Clearly significant amounts of runoff left the application field and moved thousands of meters into drainage ways and neighboring properties. The movement was tracked, documented and mapped with GIS tools and software. Vulnerable wells in the surrounding area were monitored and tested. It was not until a later snowmelt event on April 3, 2013, when manure contaminated runoff was discovered entering groundwater (Larsen, 2013).

Runoff entered the ground water through a subtle, newly discovered sinkhole. The swallow hole was only 5 centimeters in diameter; however it was accepting large amounts of runoff.

The Wiskow dye traces were completed in spring of 2014 as a result of the manure contaminated runoff incidents of March 2013. Many participating agencies were involved. The traces were completed by Jeff Green and Scot Johnson of the Minnesota Department of Natural Resources (DNR) Ecological Water Resources Division, Martin Larsen of the Olmsted County Soil and Water Conservation District and E. Calvin Alexander, Jr. of the University of Minnesota Earth Sciences Department.
Two sinkholes were identified in the Prosser formation to be used in the trace. One, the small newly identified sinkhole on the Wiskow property; (MN55:D00983) located at $557550 \mathrm{E} / 4865569 \mathrm{~N} \pm 3.9 \mathrm{~m}$. On May 6, 2104, 1,095 grams of 35 wt. \% Uranine C dye (often called fluorescein) was introduced into the sinkhole. A skid loader excavated a basin in the area of the very small swallow hole. 1,100 liters (300 gallons) of fresh water was first injected into the bowl. Dye was injected next (Figure 6) followed by 2,300 liters (700 gallons) of water. Initially, drainage was very slow and the water ponded for nearly an hour; thereafter, it quickly flushed into the ground. (Johnson et al., 2014).

Another sinkhole, approximately 2 kilometers south of the Wiskow property was located on the Applen property to introduce dye (MN55:D00282) found at 557516 E / $4865569 \mathrm{~N} \pm 3.3 \mathrm{~m}$. The sinkhole is approximately 21 meters in diameter, 9 meters deep with a 1 meter swallow hole in the bottom. Injection included 750 liters (200 gallons) of water followed by 435 grams $17.7 \mathrm{wt}$ $\%$ Rhodamine WT dye and 3,000 liters (800 gallons) of additional water (Johnson, et al., 2014).

Twelve springs resurging from the Prosser and Cummingsville Formations in the area were identified

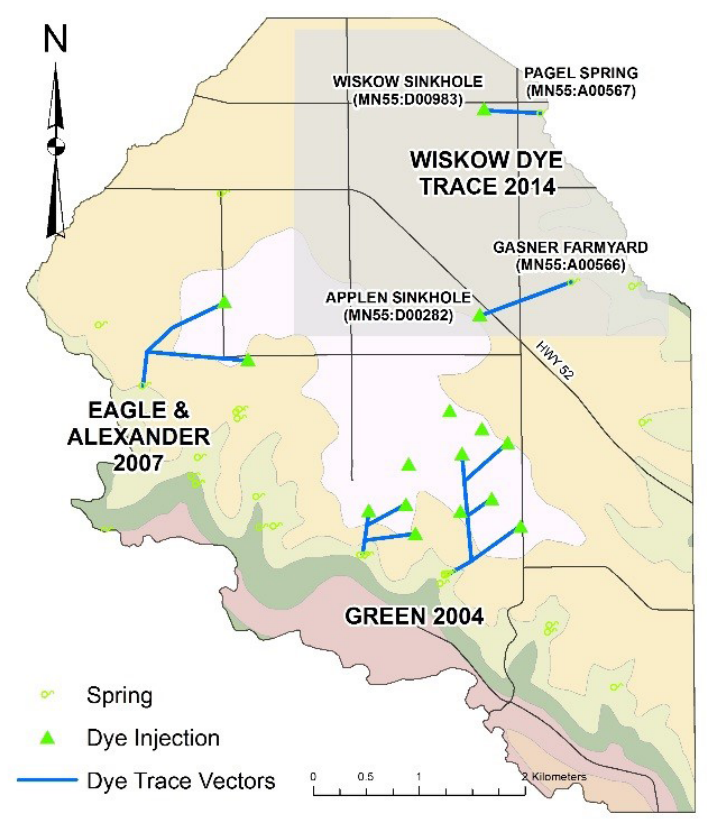

Figure 5. A map of the Orion Sinkhole Plain area with the locations of previous dye traces and the dye vectors that were assigned during the 2014 Wiskow Dye Traces (Larsen, 2014). 


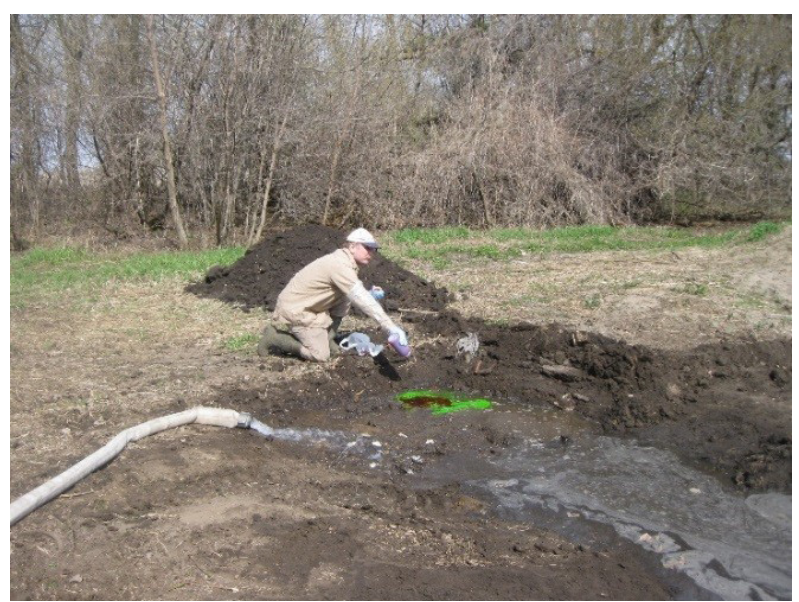

Figure 6. Technician introducing Uranine $C$ into the shallow excavated Wiskow sinkhole (Larsen, 2014).

for sampling. Two vulnerable domestic wells were monitored.

Rhodamine WT was traced from the Applen sinkhole (MN55:D00282) to the newly mapped Gasner Farmyard Spring (MN55:A00566). The dye took less than one day to reach the spring at a minimum velocity of 922 meters $(3,025$ feet $)$ per day. Dye was detected in the spring for the remainder of the sampling period.

Uranine $\mathrm{C}$ was traced from the Wiskow sinkhole (MN55:D00983) to the newly mapped Pagel Spring (MN55:00567). The dye took two days to reach the spring at a minimum approximate velocity of 278 meters (913 feet) per day.

Rhodamine WT or Uranine C was not detected at any other sample location. Surface water entering the karst system through the sinkholes studied in the Wiskow Dye trace does not appear to leave the Prosser Formations. Dye was not detected in the lower Cummingsville Formation springs.

\section{Case Study 2 - Studying a Sinkhole for Pollution Abatement}

In the spring of 2013, a new sinkhole formed in proximity to an existing feedlot in the Orion Sinkhole Plain. Initially the owner tried to fill the sinkhole on his own; however in the spring of 2014 the sinkhole was reactivated at the surface. The farmer then contacted the Olmsted County Soil and Water Conservation District for assistance in correcting the potential pollution hazard.
In July 2014; Natural Resources Conservation Service (NRCS) personnel and an Olmsted County Soil and Water Conservation District employee met on site to perform a detailed survey of the sinkhole. Soil borings were taken to determine the depth to bedrock around the perimeter of the sinkhole. Multiple cross sections were taken with ground penetrating radar (Figures 7 and 8).

NRCS recommended the sinkhole be fully excavated to bedrock and locate the conduit system. The conduits would be covered with select stone drain material followed by a non-woven geotextile liner. The largest portion of the sinkhole filled with compacted engineered soils.

\section{Case Study 3 - Blue Ridge Confined Animal Feeding Operation}

Schoenfelder Farms owns a large confined animal feeding operation (CAFO) named Blue Ridge. Blue Ridge is centrally located in the sinkhole plain. The feedlot was initially permitted by the Minnesota Pollution Control Agency (MPCA) in 1991. The Schoenfelders' have been researching solutions to modify the site so that it meets current pollution control laws. According to federal

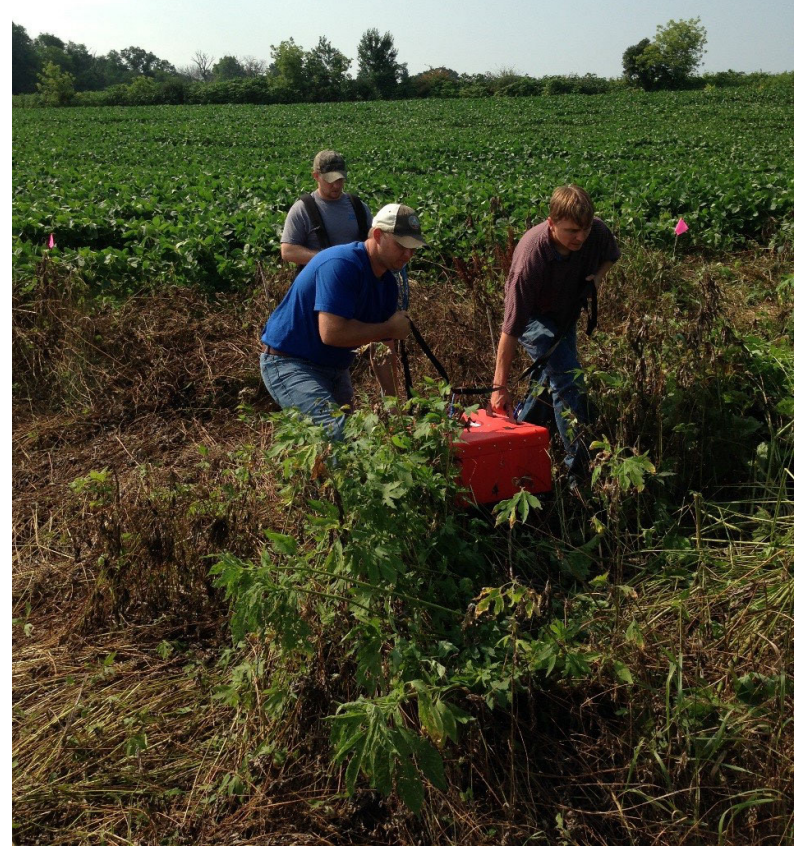

Figure 7. Technicians surveying the sinkhole with a ground penetrating radar (Larsen, 2014). 


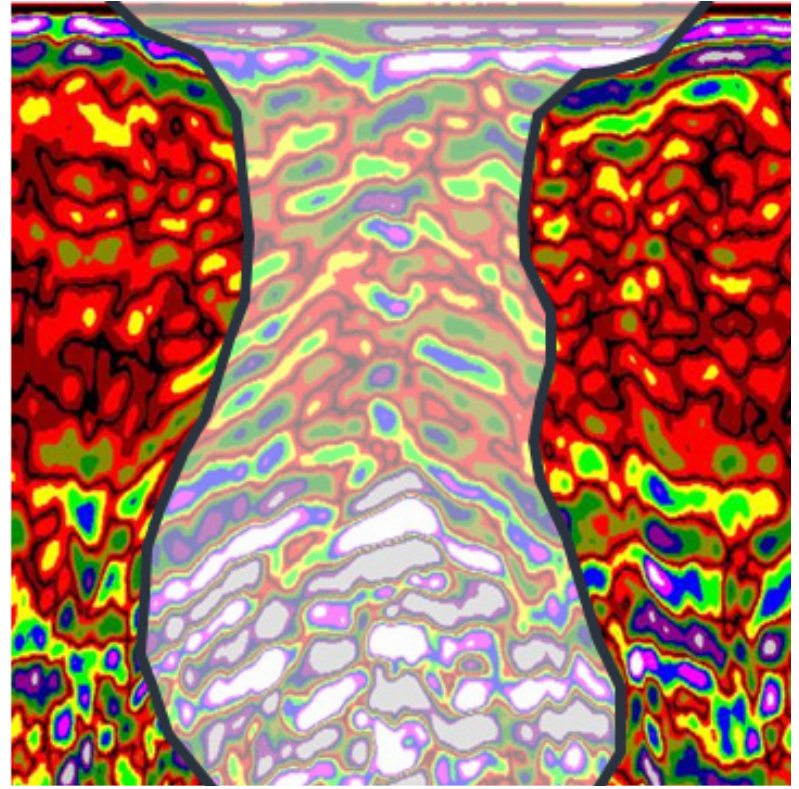

Figure 8. GPR Image of the sinkhole. The lighter areas are dense material in the bottom of the sinkhole, possibly indicating is has been filled before with debris (England, 2014).

feedlot laws, all CAFOs must comply with a "zero runoff" status and, therefore must eliminate or collect all water leaving the feedlot. Many proposals have been presented by Schoenfelder Farms and their private engineers to the MPCA, but location challenges have delayed completion of environmental corrective action for three years. In attempts to find a suitable site for a large manure storage structure, many locations have been evaluated at Blue Ridge.

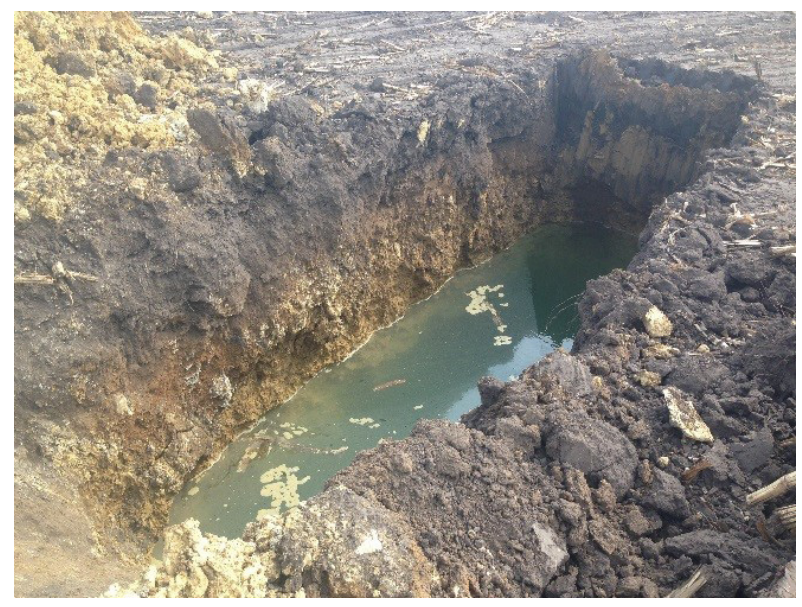

Figure 9. A 3 meter (10 foot) test pit dug at Blve Ridge to determine the depth to bedrock. Shortly after excavation that terminated at the bedrock surface, the hole filled with approximately 2 meters of water (Larsen, 2014).
Three primary challenges exist for locating the proposed storage area. Minnesota feedlot rules require the following:

- Due to the proximity of sinkholes within the plain, a liquid manure storage area (LMSA) cannot be constructed on most of the Schoenfelder property. According to Minnesota feedlot rules LMSAs must not be located within 91 meters (300 feet) of any sinkhole (Minn R. 7020.2005 Subp. 1.).

- The total size of the LMSA may not be larger than 950,000 liters (250,000 gallons) when four or more sinkholes exist within 305 meters $(1,000$ feet). The required volume for the facility is significantly more than 950,000 liters, and many sites would not allow for the 22 million liter ( 6 million gallon) structure that is needed at the Blue Ridge Site (Minn R. 7020.2100 Subp. 2. A).

- Minnesota feedlot rules require a minimum vertical separation to bedrock of 3 meters ( 10 feet) when the site has a capacity of 1,000 or more animal units (1 slaughter steer is equal to 1 animal unit). Most of the sinkhole plain has soil cover of less than 1.5 meters (Minn R. 7020.2100 Subp. 2. B. (3)).

Since the feedlot is located at the northern edge of the plain, the only potentially suitable location is 1,000 feet north in an open field. One small corner of the Schoenfelder property appears to allow for separation to sinkholes and vertical separation to bedrock. In the fall of 2014, test pits were dug with an excavator to determine separation to bedrock (Figure 9).

As of March 2015 research is continuing to find a solution that meets Minnesota Feedlot Rules and is a viable option for the Schoenfelders'.

\section{Case Study 4 - A Constructed LMSA to Protect Surface and Groundwater}

A manure contaminated runoff storage area was constructed in the fall of 2014 by a livestock producer with 275 animal units located at the headwater spring of Mill Creek (Figure 10). The structure was built to protect the stream from manure contaminated runoff. The LMSA also stores manure so that the producer can apply manure in a seasonal manner that maximizes crop nutrients and minimizes environmental risk. (Manure application considerations are described further in the next section.) Prior to construction manure contaminated runoff discharged directly into the creek. 


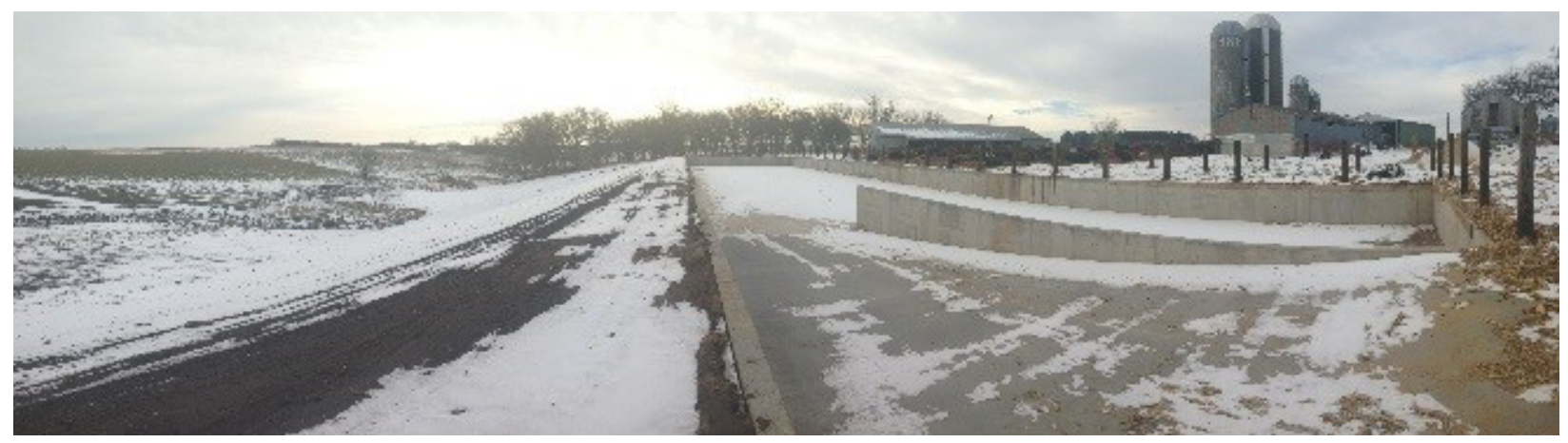

Figure 10. Completed LMSA that intercepts manure contaminated runoff leaving the feedlot edge before it reaches Mill Creek on the downstream (Larsen, 2014).

The project was in the planning stages for many years. The LMSA was re-designed when it was discovered that soil was very thin. The redesign significantly increased the cost of the structure for the producer. Permitting and contractor services also took longer than expected.

The LMSA was constructed so that contaminated water from the existing feedlot flows directly into the structure, and diversions on each end keep contaminated water from bypassing the system. The producer can also push manure into the LMSA from the existing feedlot. A concrete ramp is used so the landowner can thoroughly clean out any solids.

Where the capacity of the feedlot is less than 300 animal units, Minnesota feedlot rules require LMSAs to be constructed with a minimum of 1.5 meters (five feet) vertical separation to bedrock. Because there was an existing pollution hazard at this site, Minn. R. 7020 feedlot rules allowed construction.

In order to alleviate environmental concerns associated with storing manure within 18 centimeters to bedrock, the LMSA was constructed with two liners. The first is 15 centimeters of reinforced concrete. The concrete was designed to withstand pressures from larger cleaning equipment. Waterstop was installed to seal all concrete joints and make them water tight. The concrete is underlain by a 60 mil LPDE liner that is attached 15 centimeters below the top of the 1.8 meter sidewalls of the structure. Between the liners, Form-a-drain tm allows gravity drainage of any potential leachate from the concrete to a surface tile outlet. The outlet serves as an inspection point that is regularly monitored should a problem arise with the concrete liner. Perimeter drain tile is also installed around the footing of the LMSA. The purpose of the drain tile is two-fold. It controls groundwater around the LMSA and collects any potential leachate. The drain tile water is also inspected at the same location as the interior form-adrain (Fryer, 2015, written communication).

\section{Considerations of Manure Application on Karst}

Manure application on the land surface is not necessarily a bad thing if it is done carefully and all laws, regulations and best management practices are followed. Crop nutrient prices have escalated exponentially in the past five years and manure contains costly nutrients that crops require. Detailed nutrient management plans assist producers with application method, timing and rates applied.

Following the severe runoff incidents in March 2013; the Olmsted SWCD developed manure application standards that are being presented to livestock producers in Olmsted County. In most cases the standards exceed Minnesota feedlot rule requirements. The standards are intended to limit the risk of manure contaminated runoff reaching ground water in karst areas.

In regards to manure applications on snow covered or frozen soils; the watersheds of open sinkholes appear to be most vulnerable (Figure 11). Collaborating to identify and communicate these risks has been productive. In general the consensus with producers is that 91 meter (300 feet) may not adequate for protection, and that the entire watersheds of sinkholes should not receive manure applications. 


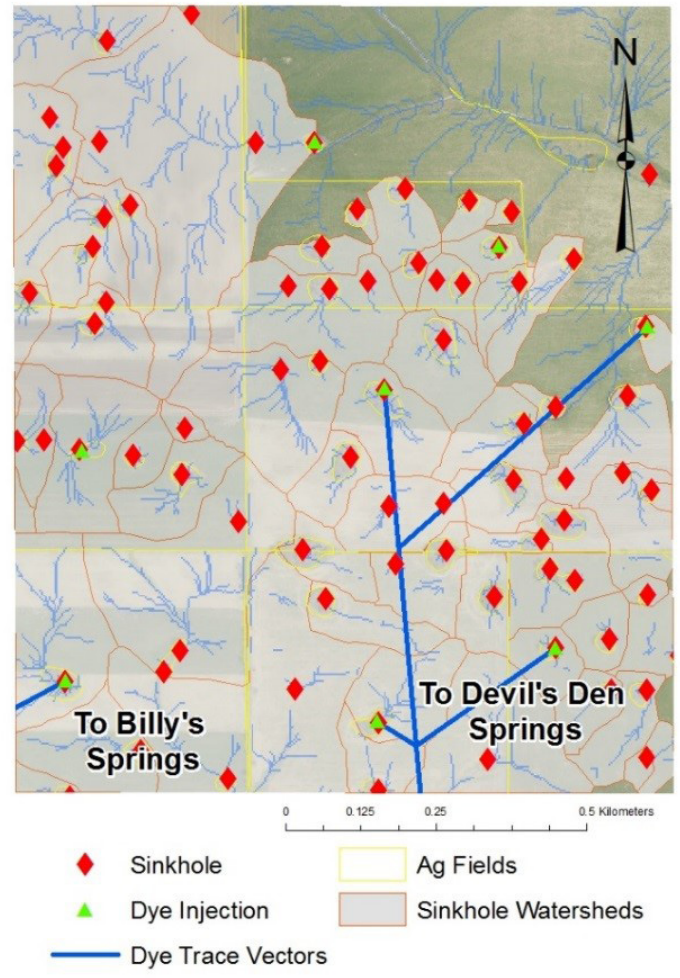

Figure 11. Karst lands and agriculture fields that drain to springs from open sinkholes (Larsen, 2014).

More recommendations were developed:

- In karst areas (where carbonate bedrock is present), producers should identify and understand:

- Areas where bedrock limits tillage or drain tile installation or drainage ditch depth.

- Presence of sinkholes, springs, closed depressions in or near fields that may fill and drain rapidly. Sinkhole application setbacks are required by feedlot rules (Minn. R. 7020.2225, Subp 6. A-C.)

- Areas where runoff water or tile discharge disappears into the ground.

- Known or potential locations of abandoned wells or cisterns. Feedlot rules contain well setbacks including wells that are abandoned. (Minn. R. 7020.2225, Subp 6. A-C.)

- Locations of wells used for any private, water supply wells

- Historical water quality problems in the area, such as short- and long-term water quality/quantity problems related to the ground -water system.
- Do not winter apply manure when weather forecasts include rain and snow melt.

- Regarding manure applications, producers should use standards above 7020 rule requirements, including more restrictive setbacks during winter applications completed after December 31.

- Avoid application to aged snow pack that is crystalline in nature and contains high moisture content.

- Modify tillage practices to reduce the impact to exposed bedrock outcrops. Contour tillage should be used at all times.

- Regarding newly acquired application acres:

- Producers should meet owners of adjacent properties before spreading manure at new sites, explain manure management practices and ask about well types and locations so that pro-active steps can be taken to reduce groundwater contamination risk.

- Keep manure application rates low at first when spreading at a location that is new to the operation or has had little or no recent manure history.

- When new land is acquired, talk to previous operators, if available, about abandoned wells, shallow bedrock, sinkholes or places where water disappears into the ground.

- Provide educational workshops to all livestock producers within active karst and close bedrock soils to communicate that vigilance and management is essential for protection of water resources.

\section{Continued Challenges}

The challenges continue for livestock producers protecting water resources in karst systems. Preventing all contamination of ground water is expensive and very difficult to achieve. However, it does not alleviate the responsibility that landowners have to greatly reduce the potential for contaminants entering aquifers.

Acute, catastrophic events may occur when karst features are unknown, when they develop quickly, or when they are underestimated by engineers and regulators. Tools such as electrical resistivity imaging will continue to be more efficient in detecting hidden karst features. However, implementing the new geophysics tools may not be required for construction of a manure storage area. 


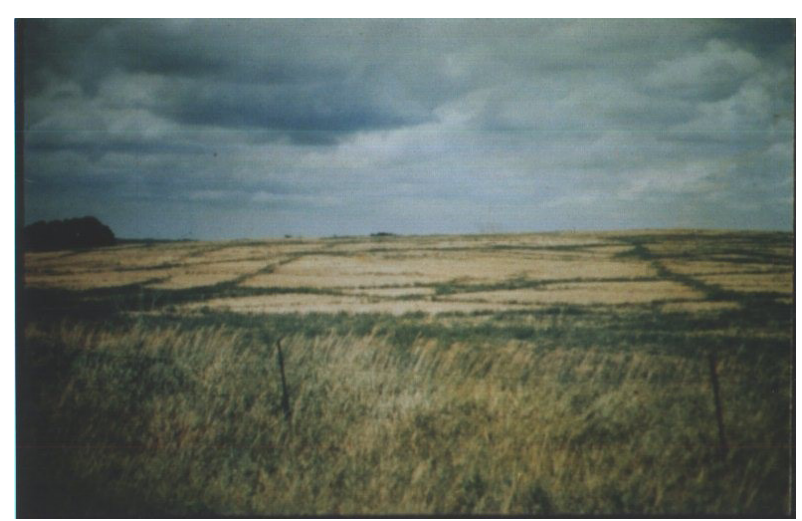

Figure 12. Fracture traces in the Ordovician Prosser Formation. Rochester Township, Olmsted County (Peter et al., 1976).

Large, weathered joints that commonly cut through many bedrock formations are typically spaced $9-30$ meters apart (Alexander, et al., 1995). These joints are usually sediment filled as seen in Figure 12. They may also be enlarged through solution and become an integrated conduit system capable of carrying large amounts of water; therefore increasing probability of sinkhole formation.

Proposed LMSAs may be 90 meters in dimension and constructed over many vertical bedrock joints. Currently, Minnesota feedlot rules require:

"A minimum of two soil borings within the boundaries of the proposed manure storage area for the first one-half acre of surface area. A minimum of one additional location is required for each additional one acre of surface area for the manure storage area." (Minn. R. 7020.2100, Subp 4. A. (2))

The soil borings are only one small picture of the karst system below and rarely provide enough information to indicate the presence of karst features.

Figure 13 provides an illustration of an LMSA constructed over carbonate bedrock to meet current Minnesota feedlot rules. Clearly there is a risk of missing potential dangers beneath soil covers greater than 10 feet.

Bedrock removal, in order to create required separation has occurred in many instances in Olmsted County (Figure 14). The outcomes of removing bedrock in order to achieve separation are not clear. Potential advantages may be that a clean bedrock surface can be inspected for areas of preferential flow or enlarged solution. When engineered soils are placed on top of the bedrock, the material between the stored manure and bedrock is homogeneous with known compaction and density. There is, however a risk that the interaction between surface and groundwater flow is impacted, creating preferential conditions for sinkhole development.

\section{Conclusion}

The four case studies outlined provide excellent educational, informational and examples for future engineering and operational proposals.

Case Study 1 is a detailed example how risk of water pollution exists, even when all applicable manure application guidelines are followed. The dye tracing study that followed the runoff incident indicates groundwater flow and resurgence.

Case Study 2 shows that dynamic karst terrain is difficult to predict, and that karst features may appear quickly. Survey and studies are valuable for remediation if the new or existing karst features present an elevated risk of groundwater contamination.

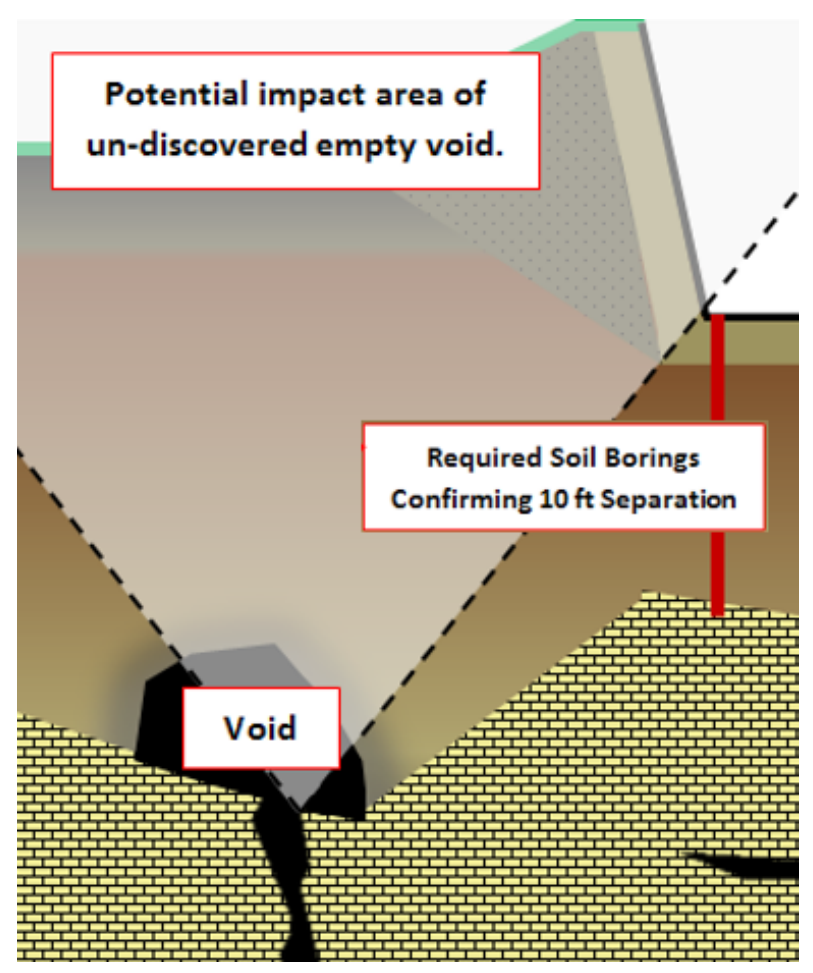

Figure 13. Illustration of an LMSA constructed over carbonate bedrock with an undiscovered void (Larsen, 2015). 


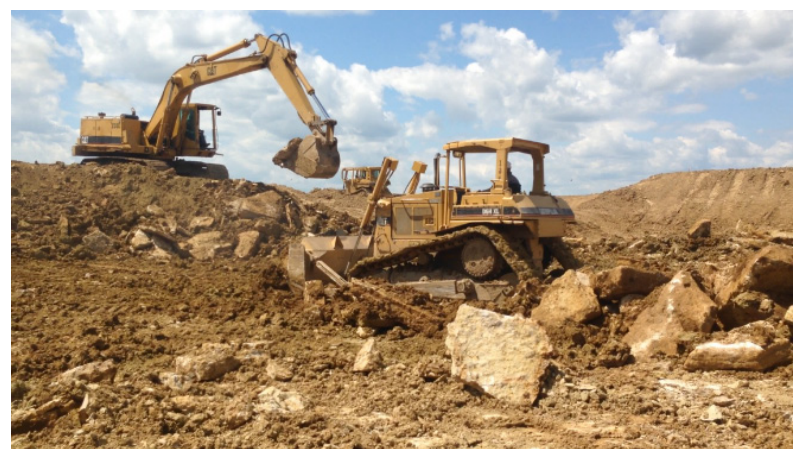

Figure 14. Limestone bedrock in process of removal from the floor of an LMSA (Larsen, 2014).

Case studies 3 and 4 are examples of real investment into environmental protection from multi-generation family farms. The setting and engineering of practices may be extensive, costly and take time.

Ongoing manure application and engineering challenges need to be continually discussed and researched between livestock producers, engineers, scientists and regulators so that pollution reduction practices can be designed, implemented and funded.

Building excellent relationships with producers has been successful in Olmsted County. Livestock producers are making investments and taking action. Producers are an essential component of the mid-western economy and assistance with information, funding and resources will help protect the environment and keep farms profitable for future generations.

\section{References}

Alexander EC Jr., Lively RS. 1995. Karst - aquifers, caves, and sinkholes. Lively RS, Balaban NH, editors, Text supplement to the Geologic Atlas Fillmore County. County Atlas Series C-8, Part C. Minnesota Geological Survey. p. 10-33.

Alexander EC Jr., Maki GL. 1988. Sinkholes and sinkhole probability. Plate 7 in Geologic Atlas of Olmsted County, Minnesota. County Atlas Series, Atlas C-3. Minnesota Department of Natural Resources, St. Paul.

Eagle SD, Alexander EC, Jr. 2007. Morehart Farm Dye Trace. 2 July 2007.

England M. 2014. GPR Image of the Sinkhole [Ground Penetrating Radar Derived Image]. Unpublished.

Green JA. 2004. Burnap Farm Dye Trace. Unpublished. Johnson SB, Green JA, Larsen MR, Kasahara BJ, Alexander EC, Jr. 2014. Wiskow Dye Traces, Olmsted County, Minnesota.

Larsen MR. 2013. Eyota Township manure runoff incident. Unpublished.
Larsen MR. 2014. Technicians surveying the sinkhole. Unpublished photograph.

Larsen MR. 2014. Technician introducing Uranine C. Unpublished photograph.

Larsen MR. 2015. Illustration of an LMSA constructed over carbonate bedrock. Unpublished illustration.

Larsen MR. 2014. Limestone bedrock in process of removal. Unpublished photograph.

Larsen MR. 2014. Completed LMSA. Unpublished photograph.

Larsen MR. 2014. A 3 meter test pit. Unpublished photograph.

Larsen MR. 2015. A state location map of the Orion Sinkhole Plain. Unpublished digital GIS map assembled by querying data from Minnesota Department of Transportation. Available from http://www.dot.state.mn.us/maps/gdma/gis-data. html.

Larsen MR. 2015. Map of the Orion Sinkhole Plain. Unpublished digital GIS map digitized from Alexander EC Jr., Maki GL. 1988. Sinkholes and sinkhole probability. Plate 7 in Geologic Atlas of Olmsted County. Olsen BM. 1988. Bedrock Geology. Plate 2 in Geologic Atlas of Olmsted County.

Larsen MR. 2015. Map of the Orion Sinkhole Plain with locations of previous dye traces. Unpublished digital GIS map digitized from Alexander EC Jr., Maki GL. 1988. Sinkholes and sinkhole probability. Plate 7 in Geologic Atlas of Olmsted County. Olsen BM.1988. Bedrock Geology. Plate 2 in Geologic Atlas of Olmsted County. Green JA. 2004. Burnap Farm Dye Trace. Eagle SD, Alexander EC Jr. 2007. Morehart Farm Dye Trace. 2 July Johnson SB, Green JA, Larsen MR, Kasahara BJ, Alexander, EC Jr. 2014. Wiskow Dye Traces Olmsted County, Minnesota.

Larsen MR. 2015. Karst lands and agricultural fields. Unpublished digital GIS map digitized from Alexander EC Jr., Maki GL. 1988. Sinkholes and sinkhole probability. Plate 7 in Geologic Atlas of Olmsted County. Green JA. 2004. Burnap Farm Dye Trace. Eagle SD, Alexander, EC Jr. 2007. Morehart Farm Dye Trace. 2 July.

Larsen MR, Williams R. 2014. MinnFARM Models of feedlots in Orion Township. Unpublished.

Peter W, Woxland W. 1976. Fracture traces. Unpublished photograph.

United States Department of Agriculture / Natural Resources Conservation Service. 1995. RCA Issue Brief \#7 [Internet]. Available from http:// www.nrcs.usda.gov/wps/portal $/ \mathrm{nrcs} / \mathrm{detail} / /$ ?cid= nrcs143 014211.

Schmidt S. 2013. A pail of foaming water. Unpublished photograph. 